\title{
Genetic variation and phylogenetic relationships of Thelymitra javanica (Orchidaceae: Orchidoideae) in East and Central Java, Indonesia
}

\author{
I MADE SAKA WIJAYA ${ }^{1, \boldsymbol{\vartheta}}$, BUDI SETIADI DARYONO², PURNOMO $^{3}$ \\ ${ }^{1}$ Program of Biology, Faculty of Mathematics and Natural Sciences, Universitas Udayana. Jl. Raya Kampus Unud No. 9, Jimbaran, Kuta Selatan, Badung \\ 80361, Bali, Indonesia. Tel.: +62-361-701954, "email: imsakawijaya@ gmail.com \\ ${ }^{2}$ Laboratory of Genetics and Breeding, Faculty of Biology, Universitas Gadjah Mada. Jl. Teknika Selatan, Sleman 55281, Yogyakarta, Indonesia \\ ${ }^{3}$ Laboratory of Plant Systematics, Faculty of Biology, Universitas Gadjah Mada. Jl. Teknika Selatan, Sleman 55281, Yogyakarta, Indonesia
}

Manuscript received: 2 December 2019. Revision accepted: 22 February 2020.

\begin{abstract}
Wijaya IMS, Daryono BS, Purnomo. 2020. Genetic variation and phylogenetic relationships of Thelymitra javanica Blume (Orchidaceae: Orchidoideae) in East and Central Java, Indonesia. Biodiversitas 21: 1174-1181. Thelymitra J.R. Forst \& G. Forst is a terrestrial orchid genera and mainly distributed in Australia as a center of its diversification. Moreover, Thelymitra javanica Blume is the only species of Thelymitra found in Asia, especially in Indonesia. In Australia and New Zealand, most of Thelymitra species easily found in lowland, whereas, $T$. javanica in Indonesia preferred to grows near the peaks of mountains around 2,000-3,000 $\mathrm{m}$ asl. The high altitude correlated with high light intensity and lower soil nutrients which require specific adaptation of plant to survive. The wide range of adaptation could be due to the presence of genetic variability among populations of Thelymitra. Therefore, this study was carried out to assess the genetic variability and phylogenetic relationships of T. javanica in East and Central Java. The genetic variability of Thelymitra was evaluated by molecular approaches, which is preferably utilized to determine the plant taxonomy to establish the taxonomic uncertainties. ITS-nrDNA is a popular DNA marker that widely used in phylogenetic study among various taxa. Sequences were analyses using Maximum Likelihood method with 11 in-group, 6 interspecies out-group of Thelymitra, and 2 intergeneric outgroup of Thelymitrinae subtribe. The result showed that ITS-nrDNA sequences of $T$. javanica have no variation in nucleotide compositions and showing polytomy branch in cladogram. Thelymitra javanica also has a close relationship with Thelymitra longifolia J.R. Forst \& G. Forst that are endemic to New Zealand.
\end{abstract}

Keywords: intraspecific variation, ITS-nrDNA, sun-orchids, taxonomic uncertainties, Thelymitrinae

\section{INTRODUCTION}

Indonesia is known for its biodiversity and most of its geographical area (except Papua because of its data deficient) classified as biodiversity hotspots with conservation priority that supported 16,500 of endemic plants (Myers et al. 2000). Orchid (Orchidaceae) is one of the important plants that have the highest endemicity among the plants. The endemicity of orchid caused by its adaptability in variable environments and perform a specific interaction with other organisms especially mycorrhiza (Dressler 1993; Kindlmann and Jersakova 2005; Swarts and Dixon 2009). Mycorrhiza known has a specific symbiosis with orchid roots and played an important role in growth and development of the plants (Swarts and Dixon 2009; Reiter et al. 2018). It raised the term of orchid mycoheterotrophic and holomycoheterotrophic because of its dependency on mycorrhiza.

In the world, more than 25,000 species under 800 genera of orchids were estimated (Dressler 1993; Brown et al. 2008). Orchid mainly distributed in tropical zone from the beach to the mountain as terrestrial or epiphytic plant (Dressler 1993; Brown et al. 2008; Roberts and Dixon 2008). Some orchid species are also adapted to an extreme area like Thelymitra javanica Blume that grow in sandy soil with high light intensity near the peak of the mountain in Java (Backer and v.d. Brink 1968; v. Steenis 1972; Comber 1990).

Thelymitra J.R. Forst \& G. Forst is a genus of terrestrial orchid with its center of distribution in Australia (Kalkman 1955; Backhouse 2007), and T. javanica is the only one recorded in Asia (Backer and v.d. Brink 1968; v. Steenis 1972; Comber 1990). Thelymitra javanica was first described by C.L. Blume with a specimen from Mount Gede, Indonesia (Blume 1825), and is taxonomically stable with only one revision from tribe Thelymitrideae to be Diurideae (Chase et al. 2015). In the lower taxonomical level, Thelymitra was classified in subtribe Thelymitrinae, along with Epiblema R.Br. and Calochilus R.Br. (Keros et al. 2001; Chase et al. 2015).

Tribe Diurideae consists of tuberous terrestrial orchid with a well-developed vegetative reproduction (Jeanes 2013; Weston et al. 2014) and highly ambiguous in morphology (Cameron et al. 1999; Edens-Meier and Bernhardt 2014; Hopper 2014). The morphological ambiguity is usually resolved using the molecular approaches to produce a more robust classification system. The DNA sequence is one of the molecular approaches used in the taxonomical study of orchid up to different strata of plants viz., family (Cameron et al. 1999; Chase et al. 2015), tribe, genera, species, even intra species (Yorifuji et al. 2005; Yukawa et al. 2013). 
DNA sequence utilized in determination of plant taxonomy has been rapidly developing for recent times (AlHemaid et al. 2014). Although, cytochrome c oxidase subunit 1 (COI) of mitochondrial DNA (mtDNA) is widely used as a molecular marker in animal DNA barcoding, the universal DNA region as a marker for plant has not been found yet. In plants, various types of DNA regions used for taxonomical study, but ITS-nrDNA (Internal Transcribed Spacer-nuclear ribosomal DNA) region is widely used in phylogenetic reconstruction up to family, tribe, and intraspecies level (Soltis and Soltis 1998; Douzery et al. 1999; Yukawa et al. 2013; Ali et al. 2015).

ITS is a non-coding region of the nrDNA coding region (in order 18S-ITS1-5,8S-ITS2-26S) and has a high mutation rate (Soltis and Soltis 1998; Aprilyanto and Sembiring 2016). In phylogenetic analysis, every researcher has their own preference to combine each part of ITS-nrDNA. Hribova et al. (2011) prefer to use only ITS1 and ITS2 because of its high evolution rate at the level of intraspecies or intrapopulation, while Yao et al. (2010) specifically recommend ITS2 as a universal DNA barcode for eukaryote, both in plant and animal. In this study, we also used 5,8S sequence that makes ITS-nrDNA consist of ITS1-5,8S-ITS2. By using those sequences, this study aimed to asses the genetic variability and phylogenetic relationships of $T$. javanica.

\section{MATERIALS AND METHODS}

\section{Area of the sample collection}

The samples of $T$. javanica were collected from 4 different mountains: Mount Arjuno (East Java S746'13.5' E112 37'11.6"), Mount Lawu (borderline between East and Central Java S7 $37^{\prime} 58.5^{\prime \prime}$ E111 $\left.{ }^{\circ} 11^{\prime} 44.8^{\prime \prime}\right)$, Mount Sumbing (Central Java S7²2'57.6" E11004'40.9'), and Mount Andong (Central Java S7²3'25.9” E110²2’13.7’)
(Figure 1). The coordinate of locations marked with GPS (Garmin csx64s).

\section{Procedures}

\section{Plant materials}

The leaf materials of 11 populations of $T$. javanica were collected from 4 different mountains at various altitudes (Table 1). The leaf chooses wisely, because of T. javanica only has one leaf that would affect its metabolism. We use some criteria for collecting leaf material. First, we considered the young and clean leaf to avoid its secondary metabolic that could affect DNA extraction. And second, we only collect one sample in each colony that consists of 5 individuals or more. For data records, spirit specimens were deposited in Herbarium Bogoriense, Indonesian Institute of Science (LIPI), Indonesia.

\section{Molecular methods}

DNA was extracted from $30 \mathrm{mg}$ leaves using PhytoPure Extraction Kit SL8510 (Nucleon, Tepnel Life Sciences PLC, Manchester). DNA purity checked by ratio of spectrophotometer value at $260 \mathrm{~nm}$ and $280 \mathrm{~nm}$. DNA amplification initiated if the ratio of DNA purity at the range of 1.8-2.0 that indicates the DNA extract was fairly pure to avoid miss-amplification. The ITS-nrDNA region was amplified with polymerase Chain Reaction (PCR) by using ITS5 as forward primer (5'GGAAGTAAAAGTCGTAACAAGG-3') and ITS4 as reverse primer (5'-TCCTCCGCTTATTGATATGC-3') (White et al. 1990). PCR reaction was carried out in $25 \mu \mathrm{L}$ volume that composed of $9.5 \mu \mathrm{L} \mathrm{ddH}_{2} \mathrm{O}$ (Invitrogen UltraPure Distilled Water), 12.5 $\mu \mathrm{L}$ PCR mix (Bio-25041 MyTaqTM), $1 \mu \mathrm{L}$ forward primer, $1 \mu \mathrm{L}$ reverse primer, and $1 \mu \mathrm{L}$ DNA template (DNA extract). PCR program was including 35 cycles following protocol of pre-denaturation at $95^{\circ} \mathrm{C}$ in 1 minute, denaturation at $94^{\circ} \mathrm{C} 15$ seconds, annealing at $54^{\circ} \mathrm{C}$ in 15 seconds, elongation at $72^{\circ} \mathrm{C}$ in 10 seconds, and post-elongation at $72^{\circ} \mathrm{C}$ it 2 minutes.

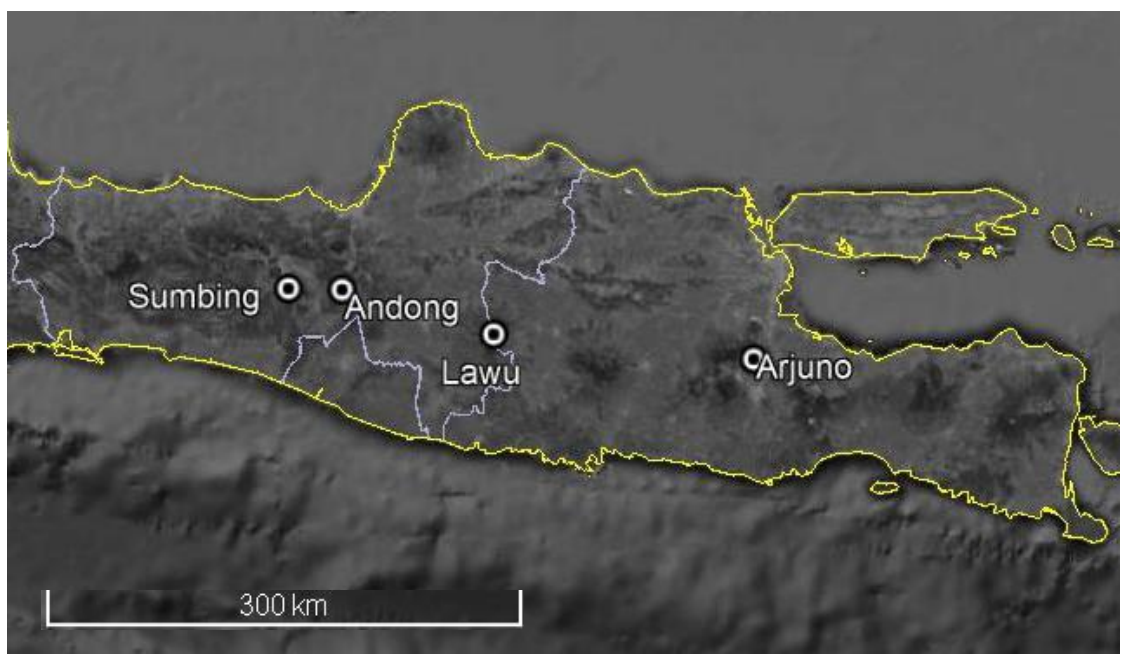

A

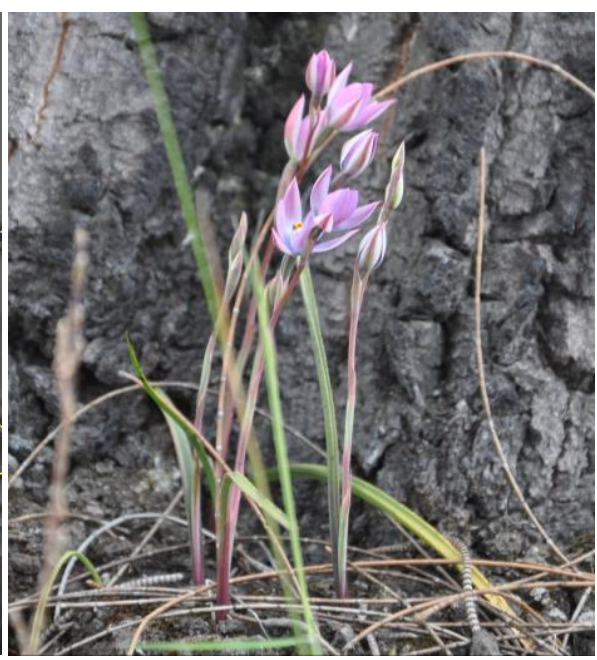

B

Figure 1. Study sites and habitus of T. javanica in East and Central Java (A) Study site in Mount Sumbing, Andong, Lawu, and Arjuno; and (B) The appearance of $T$. javanica in its habitat 
The PCR products tested by electrophoresis on $2 \%$ agarose in $1 \times$ TBE buffer with $2 \mu \mathrm{L}$ Florosafe Gel Stain. Electrophoresis using $4 \mu \mathrm{L}$ of DNA template and $3.5 \mu \mathrm{L}$ of DNA ladder, and running at $50 \mathrm{~V}$ for 60 minutes using MUPID-exU electroporator. Gel doc used to visualize electrophoresis results and checked the existence of ITSnrDNA region. The PCR products that contain ITS-nrDNA region then sequenced performed by BigDye $\AA$ Terminator v.3.1 Cycle Sequencing Kit (ThermoFisher Scientific, Life Technologies Corporation, USA).

\section{Data analysis}

The ITS-nrDNA sequences were processed as contig files in Gene Studio Pro software, then analyzed in MEGA7 (Aprilyanto and Sembiring 2015; Kumar et al. 2016; Arisuryanti et al. 2017). The sequences alignment was performed by Clustal Omega in http://ebi.ac.uk/Tools/ms/clustalo/ and copied as a nexus file by Mesquite software. The cladogram construction was done in MEGA7 with Maximum Likelihood algorithm, Kimura-2-parameter nucleotide substitution model, and 500 replicates in bootstrap analysis. Genetic variations showed in nucleotide compositions and distance matrix obtained from MEGA7 software.

The outgroup obtained by BLAST (Basic Local Alignment Search Tool) from GenBank (http://www.ncbi.nlm.nih.gov/) analysis consisting 6 species of other Thelymitra as an interspecies outgroup and 2 species from different genera but is classified in the same subtribe Thelymitrinae as an intergeneric outgroup (Table 2).

\section{RESULTS AND DISCUSSION}

\section{Genetic Variations based on ITS-nrDNA Sequences}

All samples of $T$. javanica are composed of 689 nucleotides with no variation in nucleotide composition and frequency. The ITS sequence of $T$. javanica consists of 257 bp ITS1, 167 bp 5,8S, and 265 bp of ITS2. The BLAST search for ITS sequence of $T$. javanica shows maximum identity for $T$. pauciflora $(100 \%)$ and $T$. longifolia (99\%). The other Thelymitra species are 95-97\% identity, while $C$. paludosus and E. grandiflorum have the same identity in $92 \%$.

Based on nucleotide composition after alignment, $T$. flexuosa, T. pauciflora, and E. grandiflora also contain 665 nucleotides but vary in nucleotide frequency (Table 3). The $\mathrm{G}$ content of all samples is generally above $31 \%$, except $T$. ixioides, T. pauciflora, and C. paludosus that have G content $26.8 \%, 27.8 \%$, and $28.7 \%$, respectively. In reverse, the $\mathrm{C}$ content of those three was above $31 \%$ while the others were $27.2-28.8 \%$. This composition and frequency would affect the phylogenetic tree of all taxa studied.

The distance matrix is shown in Table 4. Without nucleotide variation in $T$. javanica samples, the distance matrix shows $0.000 \%$ dissimilarity. The distance matrix also reveals the low dissimilarity of $T$. javanica within $T$. longifolia, which is $0.008 \%$. Even though T. pauciflora has the highest identity in BLAST search, the dissimilarity of $T$. pauciflora with $T$. javanica is much higher than $T$. longifolia $(1.110 \%)$.

\section{Phylogenetic Relationships based on ITS-nrDNA Sequences}

The phylogenetic tree (cladogram) derived from 616 nucleotides uses Maximum Likelihood method, Kimura-2parameter substitution model (Kimura 1980) and bootstrap with 500 replicates to ensure the robustness of the tree (Felsenstein 1985).

Cladogram of phylogenetic relationship shown in Figure 2 reveals two clades, clade I composed by $T$. javanica, T. longifolia, T. benthamiana, T. cyanea, T. flexuosa, dan E. grandiflorum, while clade II composed by T. pauciflora, T. ixioides, dan C. paludosus. Even though Epiblema (E. grandiflorum) and Calochilus (C. paludosus) are placed in the same subtribe with Thelymitra (Subtribe Thelymitrinae), E. grandiflorum is closely related with the clade I, whereas $C$. paludosus with the clade II. The three species that have similar $\mathrm{G}$ and $\mathrm{C}$ content before are all placed in clade II.

\section{Discussion}

The species diversification of Thelymitra originated in southwest Australia, then dispersed by westerly winds to reach areas far to the east; this might explain how this genus occurs in Tasmania, New Zealand, and New Caledonia (Nauheimer et al. 2018). Australia is the center of its distribution, so Thelymitra is known as Australian orchid. Only one species of Thelymitra is distributed in Asia, identified as Thelymitra javanica. This species is found in Java and Lombok (Kalkman 1955; van Steenis 1972; Comber 1990) and even recorded in Luzon, Philippines (van Steenis 1972). The occurrence of $T$. javanica in Indonesia remains unclear because its distribution has not been recorded in East Nusa Tenggara, which is nearer to Australia. T. javanica was recorded in Lombok and Java but not in Bali, which is also confusing. This could be the result of a lack of flora assessment in Bali and East Nusa Tenggara, which provides new scope of flora research in those islands.

Table 1. Sampling units of T. javanica

\begin{tabular}{lcc}
\hline \multicolumn{1}{c}{ Mount } & $\begin{array}{c}\text { Number of sampling } \\
\text { unit }\end{array}$ & Altitude (m asl.) \\
\hline Arjuno & 1 & 3,026 \\
Arjuno & 2 & 3,119 \\
Arjuno & 3 & 3,323 \\
Lawu & 1 & 2,478 \\
Lawu & 2 & 2,995 \\
Lawu & 3 & 3,243 \\
Sumbing & 1 & 3,140 \\
Sumbing & 2 & 3,193 \\
Sumbing & 3 & 3,201 \\
Andong & 1 & 1,674 \\
Andong & 2 & 1,678 \\
\hline
\end{tabular}


Table 2. List of species and their accession code for molecular analysis in this study. Samples obtained from GenBank are marked with an asterisk

\begin{tabular}{|c|c|c|}
\hline Species & Accession code & Source \\
\hline \multicolumn{3}{|l|}{ In-group } \\
\hline $\begin{array}{l}\text { Thelymitra javanica } \text { Blume Mt. Andong } \\
\text { Thelymitra javanica } \text { Blume Mt. Andong } \\
\text { Thelymitra javanica } \text { Blume Mt. Arjuno } \\
\text { Thelymitra javanica } \text { Blume Mt. Arjuno } \\
\text { Thelymitra javanica } \text { Blume Mt. Arjuno } \\
\text { Thelymitra javanica } \text { Blume Mt. Lawu } \\
\text { Thelymitra javanica } \text { Blume Mt. Lawu } \\
\text { Thelymitra javanica } \text { Blume Mt. Lawu } \\
\text { Thelymitra javanica } \text { Blume Mt. Sumbing } \\
\text { Thelymitra javanica } \text { Blume Mt. Sumbing } \\
\text { Thelymitra javanica } \text { Blume Mt. Sumbing }\end{array}$ & $\begin{array}{l}\text { MG978402 } \\
\text { MG978403 } \\
\text { MG978404 } \\
\text { MG978405 } \\
\text { MG978406 } \\
\text { MG978407 } \\
\text { MG978408 } \\
\text { MG978409 } \\
\text { MG978410 } \\
\text { MG978411 } \\
\text { MG978412 }\end{array}$ & \\
\hline \multicolumn{3}{|l|}{ Interspecies out-group } \\
\hline $\begin{array}{l}\text { Thelymitra pauciflora } \mathrm{R} . \mathrm{Br} \text {. } \\
\text { Thelymitra longifolia J.R. Forst \& G. Forst } \\
\text { Thelymitra ixioides } \mathrm{Sw} \text {. } \\
\text { Thelymitra benthamiana } \text { Rchb.f. } \\
\text { Thelymitra cyanea (Lindl.) Benth. } \\
\text { Thelymitra flexuosa } \text { Endl. }\end{array}$ & $\begin{array}{l}* \mathrm{AF} 321605 \\
* \mathrm{AF} 348070 \\
* \mathrm{AF} 321604 \\
* \mathrm{AF} 348067 \\
* \mathrm{AF} 348068 \\
* \mathrm{AF} 348069\end{array}$ & $\begin{array}{l}\text { Perkins and Weston (2000) } \\
\text { Clements et al. (2002) } \\
\text { Perkins and Weston (2000) } \\
\text { Clements et al. (2002) } \\
\text { Clements et al. (2002) } \\
\text { Clements et al. (2002) }\end{array}$ \\
\hline \multicolumn{3}{|l|}{ Intergeneric out-group } \\
\hline $\begin{array}{l}\text { Calochilus paludosus } \mathrm{R} . \mathrm{Br} \text {. } \\
\text { Epiblema grandiflorum } \mathrm{R} . \mathrm{Br} \text {. }\end{array}$ & $\begin{array}{l}* A Y 029046 \\
* A F 348029\end{array}$ & $\begin{array}{l}\text { Perkins and Weston (2001) } \\
\text { Clements et al. (2002) }\end{array}$ \\
\hline
\end{tabular}

Thelymitra javanica occupies a specific area in Java, which is near the peak of a mountain. Theoretically, its habitat could be isolated, but morphological analysis among some mountains in Java shows morphological plasticity (Wijaya et al. 2018). The molecular approach is needed to investigate any genetic variations among $T$. javanica and reveal its relationships with other Thelymitra species from Australia. The selection of markers in a molecular approach should be chosen wisely. ITS-nrDNA is a common molecular marker to assess genetic variability and has been widely used in phylogenetic reconstruction (Khademi et al. 2016). There are also many available ITSnrDNA sequences of Thelymitra in GenBank that would be useful in constructing robust phylogenetic relationships.

Based on nucleotide compositions (Table 3), $T$. javanica and $T$. longifolia have a similar GC content $(59.8 \%)$ and only have one different nucleotide, which caused the $0.0082 \%$ dissimilarity. Overall, the GC content did not show any particular implications in the cladogram in Fig. 2. Thelymitra pauciflora (GC content $59.2 \%$ ) is grouped in a different clade from $T$. javanica, while $T$. cyanea (GC content $58.8 \%$ ) is placed in the same clade as T. javanica. T. pauciflora has a different nucleotide alignment, although its nucleotide composition is similar to T. javanica (59.8\%). The similarity of nucleotide alignment, shown in the distance matrix in Table 3, indicated that the distance from $T$. javanica to $T$. pauciflora was $1.110 \%$, while the distance from $T$. javanica to $T$. cyanea was $0.040 \%$. This situation also occurred in intergeneric outgroups. Epiblema grandiflorum (GC content $58.6 \%$ ) rooted the $T$. javanica clade, while $C$. paludosus $(60.3 \%)$ was placed in the same clade as $T$. pauciflora and $T$. ixioides.

Nucleotide composition, particularly GC content, could be considered to point out genetic variations. In plants, predicted GC content interacts with genome function and ecological adaptation (Smarda et al. 2014). High GC content usually correlates to high thermal stability because of its triple hydrogen bonds. High GC content requires more energy to synthesize. This leads to misincorporation with $\mathrm{A} / \mathrm{T}$ (which cost less energy) in DNA replication, and then causes mutation (Smarda and Bures 2012). Smarda et al. (2014) conducted research of GC content in monocots and found that the GC content affected the adaptation of monocots in seasonally dry winter cold or in areas with some seasonal water deficiency.

In phylogenetic analysis of $T$. javanica, similar nucleotide compositions among 11 samples of $T$. javanica affected the polytomy branch in the cladogram. The polytomy branch also includes $T$. longifolia as the closestrelated species to $T$. javanica. This is interesting, since $T$. longifolia is a native species of New Zealand (Edens-Meier et al. 2013; Jeanes 2013). The disjunction of Thelymitra distribution based on this ITS-nrDNA sequence ignites some speculation, such as the possibility of pollination similarities that conserve the ITS-nrDNA region or the marker itself that are inadequate to construct a sufficient phylogenetic tree. 
Table 3. Nucleotide composition and frequency of $T$. javanica and out-groups. Frequency showed in percentage

\begin{tabular}{|c|c|c|c|c|c|c|c|}
\hline Spesies & $\mathbf{T}(\mathbf{U})$ & $\mathbf{C}$ & $\mathbf{A}$ & G & $\mathbf{T}(\mathbf{U})+\mathbf{A}$ & $\mathbf{G}+\mathbf{C}$ & Total \\
\hline T. javanica MG978402 & 21.1 & 28.4 & 19.1 & 31.4 & 40.2 & 59.8 & 665.0 \\
\hline T. javanica MG978403 & 21.1 & 28.4 & 19.1 & 31.4 & 40.2 & 59.8 & 665.0 \\
\hline T. javanica MG978404 & 21.1 & 28.4 & 19.1 & 31.4 & 40.2 & 59.8 & 665.0 \\
\hline T. javanica MG978405 & 21.1 & 28.4 & 19.1 & 31.4 & 40.2 & 59.8 & 665.0 \\
\hline T. javanica MG978406 & 21.1 & 28.4 & 19.1 & 31.4 & 40.2 & 59.8 & 665.0 \\
\hline T. javanica MG978407 & 21.1 & 28.4 & 19.1 & 31.4 & 40.2 & 59.8 & 665.0 \\
\hline T. javanica MG978408 & 21.1 & 28.4 & 19.1 & 31.4 & 40.2 & 59.8 & 665.0 \\
\hline T. javanica MG978409 & 21.1 & 28.4 & 19.1 & 31.4 & 40.2 & 59.8 & 665.0 \\
\hline T. javanica MG978410 & 21.1 & 28.4 & 19.1 & 31.4 & 40.2 & 59.8 & 665.0 \\
\hline T. javanica MG978411 & 21.1 & 28.4 & 19.1 & 31.4 & 40.2 & 59.8 & 665.0 \\
\hline T. javanica MG978412 & 21.1 & 28.4 & 19.1 & 31.4 & 40.2 & 59.8 & 665.0 \\
\hline T. pauciflora AF321605 & 19.4 & 31.4 & 21.4 & 27.8 & 40.8 & 59.2 & 665.0 \\
\hline T. longifolia AF348070 & 21.2 & 28.6 & 19.0 & 31.2 & 40.2 & 59.8 & 664.0 \\
\hline T. ixioides AF321604 & 19.5 & 31.1 & 22.6 & 26.8 & 43.1 & 56.9 & 668.0 \\
\hline T. benthamiana AF348067 & 20.8 & 28.8 & 18.8 & 31.5 & 40.6 & 59.4 & 669.0 \\
\hline T. cyanea AF348068 & 20.9 & 27.5 & 20.3 & 31.2 & 41.2 & 58.8 & 669.0 \\
\hline T. flexиosa AF348069 & 20.3 & 28.3 & 20.2 & 31.3 & 40.5 & 59.5 & 665.0 \\
\hline C. paludosus AY029046 & 19.8 & 31.6 & 19.9 & 28.7 & 39.7 & 60.3 & 668.0 \\
\hline E. grandiflorum AF348029 & 21.4 & 27.2 & 20.0 & 31.4 & 41.4 & 58.6 & 665.0 \\
\hline
\end{tabular}

Table 4. Matrix distance of $T$. javanica and outgroups. The number at the top row indicates the species as same as the first column

\begin{tabular}{|c|c|c|c|c|c|c|c|c|c|c|c|c|c|c|c|c|c|c|c|c|}
\hline & & 1 & 2 & 3 & 4 & 5 & 6 & 7 & 8 & 9 & 10 & 11 & 12 & 13 & 14 & 15 & 16 & 17 & 18 & 19 \\
\hline$\overline{1}$ & T. javanica MG978402 & & & & & & & & & & & & & & & & & & & \\
\hline 2 & T. javanica MG978403 & 0.000 & & & & & & & & & & & & & & & & & & \\
\hline 3 & T. javanica MG978404 & 0.000 & 0.000 & & & & & & & & & & & & & & & & & \\
\hline 4 & T. javanica MG978405 & 0.000 & 0.000 & 0.000 & & & & & & & & & & & & & & & & \\
\hline 5 & T. javanica MG978406 & 0.000 & 0.000 & 0.000 & 0.000 & & & & & & & & & & & & & & & \\
\hline 6 & T. javanica MG978407 & 0.000 & 0.000 & 0.000 & 0.000 & 0.000 & & & & & & & & & & & & & & \\
\hline 7 & T. javanica MG978408 & 0.000 & 0.000 & 0.000 & 0.000 & 0.000 & 0.000 & & & & & & & & & & & & & \\
\hline 8 & T. javanica MG978409 & 0.000 & 0.000 & 0.000 & 0.000 & 0.000 & 0.000 & 0.000 & & & & & & & & & & & & \\
\hline 9 & T. javanica MG978410 & 0.000 & 0.000 & 0.000 & 0.000 & 0.000 & 0.000 & 0.000 & 0.000 & & & & & & & & & & & \\
\hline 10 & T. javanica MG978411 & 0.000 & 0.000 & 0.000 & 0.000 & 0.000 & 0.000 & 0.000 & 0.000 & 0.000 & & & & & & & & & & \\
\hline 11 & T. javanica MG978412 & 0.000 & 0.000 & 0.000 & 0.000 & 0.000 & 0.000 & 0.000 & 0.000 & 0.000 & 0.000 & & & & & & & & & \\
\hline 12 & T. longifolia AF348070 & 0.008 & 0.008 & 0.008 & 0.008 & 0.008 & 0.008 & 0.008 & 0.008 & 0.008 & 0.008 & 0.008 & & & & & & & & \\
\hline 13 & T. pauciflora AF321605 & 0.110 & 0.110 & 0.110 & 0.110 & 0.110 & 0.110 & 0.110 & 0.110 & 0.110 & 0.110 & 0.110 & 0.134 & & & & & & & \\
\hline 14 & T. ixioides AF321604 & 1.094 & 1.094 & 1.094 & 1.094 & 1.094 & 1.094 & 1.094 & 1.094 & 1.094 & 1.094 & 1.094 & 0.1124 & 0.026 & & & & & & \\
\hline 15 & T. cyanea AF348068 & 0.040 & 0.040 & 0.040 & 0.040 & 0.040 & 0.040 & 0.040 & 0.040 & 0.040 & 0.040 & 0.040 & 0.049 & 1.168 & 1.151 & & & & & \\
\hline 16 & T. flexuosa AF348069 & 0.049 & 0.049 & 0.049 & 0.049 & 0.049 & 0.049 & 0.049 & 0.049 & 0.049 & 0.049 & 0.049 & 0.057 & 1.198 & 1.173 & 0.042 & & & & \\
\hline 17 & T. benthamiana AF348067 & 0.020 & 0.020 & 0.020 & 0.020 & 0.020 & 0.020 & 0.020 & 0.020 & 0.020 & 0.020 & 0.020 & 0.028 & 1.132 & 1.116 & 0.040 & 0.045 & & & \\
\hline 18 & C. paludosus AY029046 & 1.090 & 1.090 & 1.090 & 1.090 & 1.090 & 1.090 & 1.090 & 1.090 & 1.090 & 1.090 & 1.090 & 1.114 & 1.101 & 0.120 & 1.127 & 1.162 & 1.107 & & \\
\hline 19 & E. grandiflorum AF348029 & 0.082 & 0.082 & 0.082 & 0.082 & 0.082 & 0.082 & 0.082 & 0.082 & 0.082 & 0.082 & 0.082 & 0.091 & 1.162 & 1.138 & 0.079 & 0.075 & 0.084 & 1.148 & \\
\hline
\end{tabular}

There is a unique pollination situation between $T$. longifolia, T. javanica, and T. ixioides already known. The pollination of $T$. longifolia is dominated by self-pollination, even showing sub-cleistogamous flowering identical to a self-pollination strategy (Edens-Meier and Bernhardt 2014). Self-pollination is also dominant in T. javanica. Grown in extreme environments, $T$. javanica has a lack of pollinators and tends to self-pollination. The simple pollen wall structure in T. javanica (Wijaya et al. 2018) also supports the probability of self-pollination. Franchi et al. (2002) stated that a lack of specific pollen structure indicates desiccation-sensitive pollen, which led to shortviability pollen. If $T$. javanica had a short flowering time (the flowering time slightly differs among mountains, and the flowering stage lasts about 1-2 months), the selfpollination selection would be higher.

Both T. longifolia and T. javanica show identical reproduction systems, while $T$. ixioi0.042des is very different. T. ixioides, placed in clade II, is highly dependent on cross-pollination (Sydes and Calder 1993), which indicates high gene flow. Some species of Australia's Thelymitra also have the ability to form interspecies hybrids in nature (Edens-Meier et al. 2013). There is a possibility that the ITS-nrDNA in some species of Thelymitra are conservative and indicative of incomplete concerted evolution of nrDNA, as Hribova et al. (2011) found in Musa. 


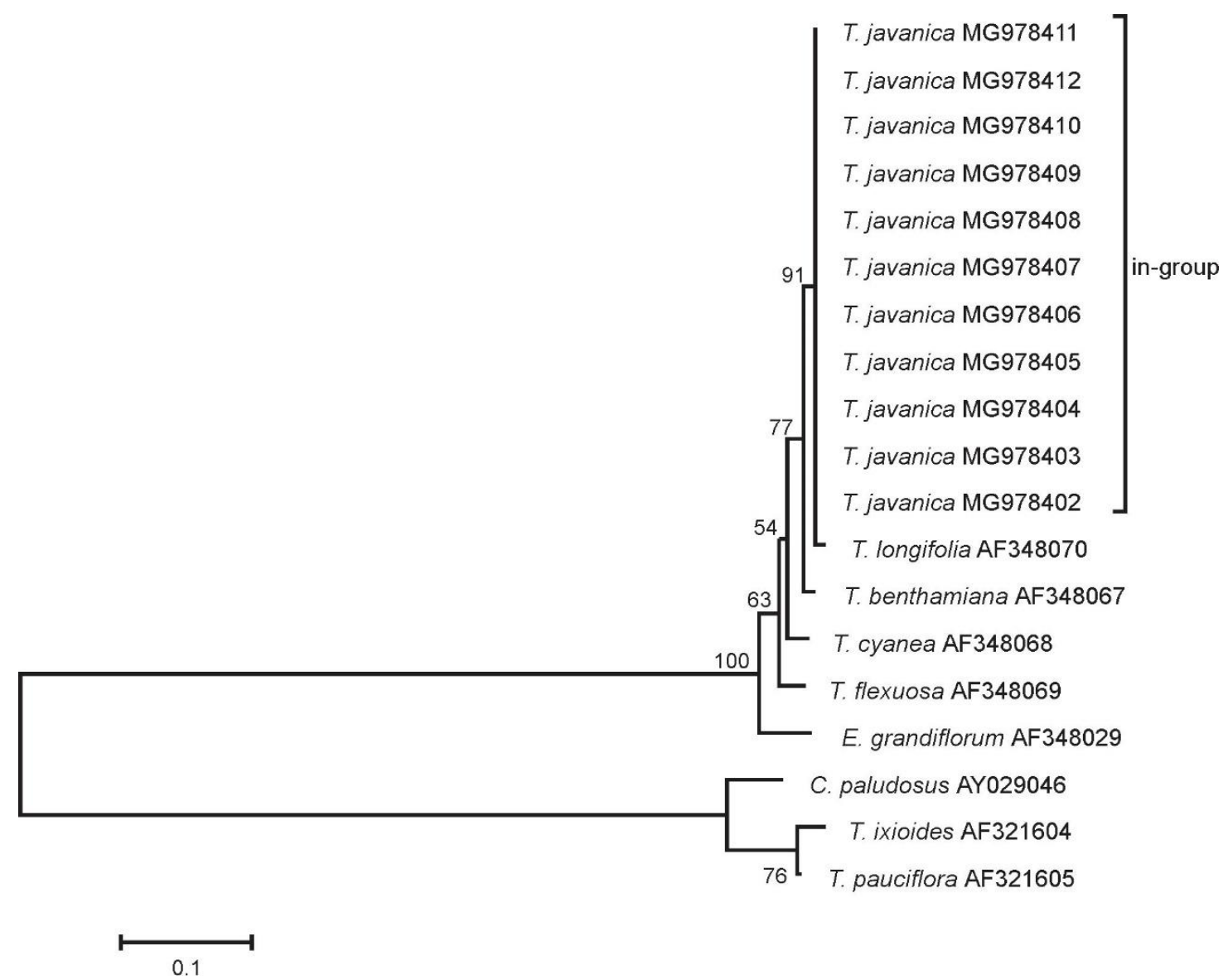

Figure 2. Cladogram of $T$. javanica based on ITS-rDNA sequences constructed by the Maximum Likelihood method with Kimura-2parameter substitution model at 500 bootstrap replicates

The utilization of ITS-nrDNA sequence in this study might be insufficient to reveal the genetic variation of $T$. javanica at the intraspecies level, although Yukawa et al. (2013) successfully used ITS-nrDNA to verify the taxonomical ambiguity of Grammatophyllum speciosum, and Purnomo et al. (2017) successfully constructed the phylogenetic relationships of water yams (Dioscorea alata L.). Khademi et al. (2016) also successfully used ITSnrDNA to investigate unresolved clades in Acer monspessulanum subspecies in Iran. The other non-coding region of nrDNA may be used in future studies, such as IGS (intergenic spacer) and ETS (external transcribed spacer), which might have a higher mutation rate at the infraspecific level (Soltis and Soltis 1998; Poczai and Hyvonen 2010). The rbcL and matK markers could also be used and combined with those nrDNA markers to produce a high resolution of phylogenetic trees.

In plant taxonomy, a molecular approach may decrease or increase taxa. Yorifuji et al. (2015) used the matK (cpDNA) sequence to find that Arundina graminifolia var. revoluta, which grows on rock formations in the middle of a river, and Arundina graminifolia var. graminifolia, which grows in the hills in West Borneo, are not a variety, but a forma. Karremans et al. (2015) use ITS-nrDNA sequence to reveal that the new species of Specklinia sp. which is morphologically described turns out to have an identical sequence with Specklinia marginata Pridgeon \& M.W. Chase. Hopper (2014) used ITS-nrDNA and found some divergence that could lead the six subgenera of Caladenia R.Br. to be the new six genera.

In conclusion, the ITS-nrDNA sequences of $T$. javanica have no variations within species. In this study, Thelymitra did not show a monophyletic branch. Thelymitra javanica is closely related to $T$. longifolia, $T$. benthamiana, $T$. cyanea, and T. flexuosa, which are rooted by Epiblema grandiflorum. In the other branch, T. pauciflora is closely related with $T$. ixioides and rooted by $C$. paludosus. We hope the ITS-nrDNA sequences of $T$. javanica represents the Thelymitra species in the Asia region.

The utilization of a molecular approach in taxonomical study has its own specification in determining taxonomical status. Although the ITS-nrDNA sequences of $T$. javanica did not show any variation within species, the occurrence of this plant in Java was evidence of disjunction in plant dispersal, and the plant should be wisely conserved. Since the distribution is mainly at the peak of mountains or at least $2000 \mathrm{~m}$ above sea level, the population pattern of $T$. javanica shows a uniquely separated gene pool. This gene pool pattern easily faces extinction by the vortex of extinction mechanism if the population remains in low 
density. The population size of $T$. javanica should be assessed to determine its conservation status; this should be done quickly to prevent genetic loss. Swarts and Dixon (2009) found drastic losses of orchid species were caused by habitat fragmentation, disappearance of key species, increased fire threat, pollinator decline, and introduction of feral animals. Some of those major threats happened in Indonesia, such as the trend of mass hiking that caused habitat fragmentation and fires that impacted the disappearance of the orchid mycorrhizal fungi and its pollinator. Fires, which have occurred in some mountains over the past three years, could also burn the tubers of $T$. javanica as the main vegetative reproductive mechanism. Without mycorrhiza and pollinators, the orchids may not last much longer (Swarts and Dixon 2009; Reiter et al. 2018). Based on the distribution pattern and threats faced by $T$. javanica, the conservation of this species should be regulated.

\section{ACKNOWLEDGEMENTS}

Thanks to the Ministry of Education and Culture of Indonesia for the college funding through Beasiswa Unggulan Program, Faculty of Biology, Universitas Gadjah Mada, Yogyakarta, Indonesia for the research funding through program "Penelitian Biodiversitas Tropika Dosen untuk Pengembangan Materi Pembelajaran" from BPTTNbh 2017 with contract number $\mathrm{UGM} / \mathrm{BI} / 1766 / \mathrm{UM} / 05 / 01$. We also thank the Indonesia Institute of Sciences (LIPI) for their assistance in our research

\section{REFERENCES}

Ali MA, Lee J, Kim SY, Park SH, Al-Hemaid MA. 2015. Molecula phylogenetic analysis of internal transcribed spacer (ITS) sequences of nuclear ribosomal DNA indicates monophyly of the genus Phytolacca L. (Phytolaccaceae). Bangladesh J Plant Taxon 22 (1): 11 8.

Al-Hemaid FMA, Ali MA, Lee J, Gyulai G, Pandey AK. 2014. Application of internal transcribed spacer of nuclear ribosomal DNA for identification of Echinops mandavillei Kit Tan. Bangladesh J Plant Taxon 21 (1): 33-42.

Aprilyanto V, Sembiring L. 2016. Filogenetika Molekuler: Teori dan Aplikasi. Innosain, Yogyakarta. [Indonesian]

Arisuryanti T, Daryono BS, Handayani NSN, Aristya GR. 2017. Pelatihan Teknik Sitogenetika Genetika Molekular Bioinformatika: Analisis Sekuen DNA dan DNA Barcoding. Fakultas Biologi UGM, Yogyakarta. [Indonesian]

Backer CA, v.d. Brink RCB. 1968. Flora of Java (spermatophytes only) vol. III. Wolters Noordhoff N.V. Groningen, Netherlands.

Backhouse GN. 2007. Are our orchids save down under? A national assessment of threatened orchids in Australia. Lankesteriana 7 (1-2) $28-43$.

Blume CL. 1825. Bijdragen tot de Flora van Nederlandsch Indie. Ter Lands Drukkerij, Batavia.

Brown A, Dundas P, Dixon K, Hopper S. 2008. Orchids of Western Australia. University of Western Australia Press, Australia.

Cameron KM, Chase MW, Whitten MW, Kores PJ, Jarrell DC, Albert VA, Yukawa T, Hills HG, Goldman DH. 1999. A phylogenetic analysis of the Orchidaceae: Evidence from $r b c L$ nucleotide sequences. Am J Bot 86 (2): 208-224.
Chase MW, Cameron KM, Freudenstein JV, Pridgeon AM, Salazar G, Berg C, Schuiteman A. 2015. An updated classification of Orchidaceae. Bot J Linn Soc 177: 151-174.

Clements MA, Jones DL, Sharma IK, Nightingale ME, Garrat MJ, Fitzgerald KJ, Mackenzie AN, Molloy BPJ. 2002. Phylogenetic systematics of the Diuridae (Orchidaceae) based on the ITS and 5,8S coding region of nuclear ribosomal DNA. Lindleyana 13 (3): 135171.

Comber JB. 1990. Orchids of Java. Royal Botanical Garden, Kew.

Douzery EJP, Pridgeon AM, Kores P, Linder HP, Kurzweil H, Chase MW. 1999. Molecular Phylogenetics of Disease (Orchidaceae): A Contribution from Nuclear Ribosomal ITS Sequences. Am J Bot 86 (6): 887-899.

Dressler RL. 1993. Phylogeny and Classification of the Orchid Family. Cambridge University Press, Cambridge.

Edens-Meier R, Westhus E, Bernhardt P. 2013. Floral biology of largeflowered Thelymitra species (Orchidaceae) and their hybrids in Western Australia. Telopea J Plant Syst 15: 165-183.

Edens-Meier R, Bernhardt P. 2014. Darwin's Orchid: Then and Now. University of Chicago Press, Chicago.

Felsenstein J. 1985. Confidence limits on phylogenies: An approach using the bootstrap. Evolution 39 (4): 783-791.

Franchi GG, Nepi M, Dafni A, Pacini E. 2002. Partially hydrated pollen: Taxonomic distribution, ecological and evolutionary significance. Plant Syst Evol 234 (1-4): 211-227.

Hopper SD. 2009. Taxonomic turmoil down-under: Recent developments in Australian orchid systematics. Ann Bot 104: 447-455.

Hribova E, Cizkova J, Christelova P, Taudien S, de Langhe E, Dolezel J. 2011. The ITS1-5.8S-ITS2 sequence region in the Musaceae: structure. Diversity and use in molecular phylogeny. PLoS ONE 6 (3): e17863. DOI: 10.1371/journal.pone.0017863.

Jeanes JA. 2013. An overview of Thelymitra nuda (Orchidaceae) complex in Australia including the description of six new species. Muelleria 31: 3-30.

Kalkman C. 1955. A plant-geographical analysis of the Lesser Sunda Islands. Acta Bot Neerlandica 4 (2): 200-225.

Karremans AP, Pupulin F, Gravendeel B. 2015. Specklinia dunstervillei, a new species long confused with Specklinia endotrachys (Orchidaceae: Pleurothallidinae). PLoS ONE 10 (7): e0131971. DOI: 10.1371/journal.pone.0131971

Keros PJ, Molvray M, Weston PH, Hopper SD, Brown AP, Cameron KM, Chase M. 2001. A phylogenetic analysis of Diurideae (Orchidaceae) based on plastid DNA sequence data. Am J Bot 88 (10): 1903-1914.

Khademi H, Mehregan I, Assadi M, Nejadsatari T, Zarre S. 2016. Molecular phylogeny of Acer monspessulanum L. subspecies from Iran inferred using the ITS region of nuclear ribosomal DNA. Biodiversitas 16 (2): 168-172.

Kimura M. 1980. A simple method for estimating evolutionary rates of base substitutions through comparative studies of nucleotide sequences. J Mol Evol 16: 111-120.

Kindlmann P, Jersakova J. 2005. Floral display, reproductive success, and conservation of terrestrial orchids. Selbyana 136-144.

Kumar S, Stetcher G, Tamura K. 2016. MEGA7: Molecular evolutionary genetics analysis version 7.0 for bigger data set. J Mol Biol Evol 33 (7): 1870-1874

Myers N, Mittermeier RA, Mittermeier CG, da Fonseca GAB, Kent J. 2000. Biodiversity Hotspot for Conservation Priorities. Nature 403: 853-858.

Nauheimer L, Schley RJ, Clements MA, Micheneau C, Nargar K. 2018. Australasian orchid biogeography at continental scale: Molecular phylogenetic insights from the Sun Orchids (Thelymitra, Orchidaceae). Mol Phylogenet Evol 127: 304-319

Perkins A, Weston P. 2000. Utilization of the 18S-26S external transcribed spacer (ETS) for phylogenetic analysis of orchids. . The University of Chicago Press, USA.

Poczai P, Hyvonen J. 2010. Nuclear ribosomal spacer regions in plant phylogenetics: Problems and prospects. Mol Biol Rep 37: 1897-1912.

Purnomo, Daryono BS, Shiwachi H. 2017. Phylogenetic relationship of Indonesian water yam (Dioscorea alata L.) cultivars based on DNA marker using ITS-rDNA analysis. J Agric Sci 9 (2): 154-161.

Reiter N, Lawrie AC, Linde CC. 2018. Matching symbiotic associations of an endangered orchid to habitat to improve conservation outcomes. Ann Bot 122: 947-959.

Roberts DL, Dixon KW. 2008. Orchids. Curr Biol 18 (8): 325-329. 
Smarda P, Bures P. 2012. The variation of base composition in plant genomes. In: Wendel F, Greilhuber J, Dolezel J, Leitch IJ (eds.). Plant Genome Diversity Vol. 1. Springer, Vienna.

Smarda P, Bures P, Horova L, Leitch IJ, Mucina L, Pacini E, Tichy L, Grulich V, Rotreklova O. 2014. Ecological and evolutionary significance of genomic GC content diversity in monocots. PNAS 4096-4102 www.pnas.org/cgi/doi/10.1073/pnas.1321152111.

Soltis DE, Soltis PS. 1998. Choosing an approach and an appropriate gene for phylogenetic analysis. In: Soltis PS, Soltis DE, Doyle JJ (eds) Molecular Systematics in Plants II: DNA sequencing. Kluwer Academic Publisher, New York.

Swarts ND, Dixon KW. 2009. Terrestrial orchid conservation in the age of extinction. Ann Bot 104: 543-556.

Sydes MA, Calder DM. 1993. Comparative reproductive biology of two sun-orchids; the vulnerable Thelymitra circumsepta and the widespread T. ixioides (Orchidaceae). Aust J Bot 41 (5): 577-589.

van Steenis CGGJ. 1972. Flora of Mountain Java. LIPI, Bogor.

Weston PH, Perkins AJ, Indsto JO, Clements MA. 2014. Phylogeny of Orchidaceae Tribe Diuridae and Its Implications for the Evolution of Pollination Systems. In: Eiden-Meier R, Bernhardt P (eds) Darwin's Orchids: Then and Now. The University of Chicago Press, USA.
White TJ, Bruns T, Lee S, Taylor J. 1990. Amplification and direct sequencing of fungal ribosomal RNA genes for phylogenetics. In: Innis M, Gelfand D, Sninsky J, White T (eds) PCR protocols: A guide to methods and applications. Academic Press, California.

Wijaya IMS, Daryono BS, Purnomo. 2018. Morphological variations of terrestrial orchid Thelymitra javanica Blume (Orchidaceae: Orchidoideae) in Mount Arjuno, Lawu, and Sumbing, Java-Indonesia. Floribunda 6 (1): 22-31.

Yao H, Song J, Liu C, Luo K, Han J, Li Y, Pang X, Xu H, Zhu Y, Xiao P, Chen S. 2010. Use of ITS2 region as the universal DNA barcode for plants and animals. PLoS ONE 5 (10): e13102. doi:10.1371/journal.pone.0013102.

Yorifuji E, Ishikawa N, Okada H, Tsukaya H. 2015. Arundina graminifolia var. revoluta (Arethusae, Orchidaceae) has fern-type rheophyte characteristics in the leaves. J Plant Res 128: 239-247.

Yukawa T, Kinoshita A, Tanaka N. 2013. Molecular Identification Resolves Taxonomic Confusion in Grammatophyllum speciosum Complex (Orchidaceae). Bull Natl Mus Nat Sci Ser B 39 (3): 137145 . 